This is an electronic reprint of the original article. This reprint may differ from the original in pagination and typographic detail.

Author(s): Tampere, Päivi; Tampere, Kaja; Luoma-aho, Vilma

Title: $\quad$ Facebook discussion of a crisis : authority communication and its relationship to citizens

Year: $\quad 2016$

Version:

Please cite the original version:

Tampere, P., Tampere, K., \& Luoma-aho, V. (2016). Facebook discussion of a crisis : authority communication and its relationship to citizens. Corporate Communications, 21(4), 414-434. https://doi.org/10.1108/CCIJ-08-2015-0049

All material supplied via JYX is protected by copyright and other intellectual property rights, and duplication or sale of all or part of any of the repository collections is not permitted, except that material may be duplicated by you for your research use or educational purposes in electronic or print form. You must obtain permission for any other use. Electronic or print copies may not be offered, whether for sale or otherwise to anyone who is not an authorised user. 


\title{
Facebook discussion of a crisis: authority communication and its relationship to citizens
}

Päivi Tampere and Kaja Tampere, Tallinn University

Vilma Luoma-aho, University of Jyväskylä

\begin{abstract}
Purpose - The purpose of this paper is to investigate the authority communication and its relationship to citizens during a disaster. This analysis is crucial for organisations to help them understand the different ways in which crises are perceived by citizens, and the reactions they may cause. The results will help authorities in planning their crisis communication.
\end{abstract}

Design/methodology/approach - Facebook comments written by authorities and citizens are studied and analysed in an exploratory case study related to the 2011 catastrophe in the Fukushima Dai-ichi nuclear power plant via content analysis.

Findings - The analysis of Facebook comments revealed that authorities have to be prepared for communicating with citizens with diverging interests, who have different perceptions on a crisis and that relation is not the same with those different profiles of citizens. Research limitations/implications - This case study only focusses on the Fukushima debate from the point of view of the authorities and citizens.

Practical implications - This study argues that it is crucial for both authorities and public relations practitioners to acknowledge that competing opinion holders are challenging each other and authority online, and that crisis communication should be planned accordingly.

Originality/value - The participant profiles can help organisations to clarify citizens' crisis perceptions that can emerge in online discussions. Practitioners need to concentrate on determining how to get their voice heard so that there are perceived credible and legitimate actors.

Keywords Crisis communication, Social media, Relationship, Dialogue, Citizens, Authorities Paper type Research paper 


\section{Introduction}

We are living in a network society where information is shared and transferred in an interaction between individuals and organisations unlimited by place or time (Castells, 2000; 2004; 2013). Organisations cannot control news flows or even messages anymore; therefore they have to compete against other sources to be heard (Luoma-aho and Vos, 2010). Veil et al. (2011; p. 111) phrase it well: "the news of a crisis can be shared and re-shared, reaching millions of people without the intervening presence of a journalist".

In Fukushima, Japan, on March 2010, a massive earthquake triggered a tsunami, which led to a nuclear disaster in the Dai-ichi nuclear power plant. News of the event spread in minutes to all over the world, and people started sharing Fukushima-related content in social media. Besides the general public who needed information to make sense of the situation, there were of course immediate victims affected by the crisis (Reynolds and Seeger, 2005) especially because it was the most severe nuclear accident after Chernobyl in 1986.

In Finland, the disaster caused a crisis in communication creating a situation where citizens and journalists were asking for information and explanations about what had happened, although they were not in physical danger. Due to the rapidly increased need for information, the Finnish Nuclear and Radiation Safety Authority (STUK) formed a crisis management team and started to follow the situation in Dai-ichi around the clock to provide information to the public and the media. And a Facebook profile was created for crisis communication purposes.

STUK is an independent public authority, whose objective is "to protect people, society, the environment, and the future generations from the detrimental effects of radiation" by regulating the use of nuclear energy, conducting research and consulting in Finland and abroad. There are approximately 360 professionals working in STUK organised, instructed and trained to operate during different radiation and nuclear accident situations (STUK Finnish Radiation and Nuclear Safety Authority, 2015).

Since there has not been much academic research on authority communication and relationship to citizens during a crisis in social media, this study analysed communication on STUK's Facebook page during the Fukushima nuclear disaster in Japan from authority's perspective. This particular disaster was chosen because it is still one of the few long-lasting 
events where state authorities have used social media as part of their crisis communication. The purpose of the study was to find out the information needs of citizens and the state of the relationship between public authorities and citizens in order to provide information to public authorities on using social media as an environment for crisis communication. Based on the Facebook comments, five different participator profiles were formed: Information and Aid Providers, Worrywarts, Sceptics, Scaremongers, and Authority Defenders. These profiles help organisations to better understand the relationships in the new media environment, as well as facilitate negotiations with citizens during a crisis.

\section{Literature review}

\subsection{The purpose of crisis communication}

Crises can be divided into two categories; organisational crises and disasters. Organisational crises can be further divided into two categories of traditional and social media crises (Coombs, 2014). Disasters are large-scale non-routine events and require multi-authority and non-routine actions (Ulmer, et al., 2011; Sutton, et al., 2008), thereby elevating expectations for communication.

Crisis communication has previously been seen as part of public relations activities, to strategically manage crises and minimise damage to organisations and its stakeholders (Reynolds and Seeger, 2005). This approach assumes that it is the organisation who is in charge and that it can define and manage the crisis, whether it is a disaster or an organisational one. However, in the era of new information technology, global networks and mass self-communication (Castells, 2013), citizens are part of crisis communication (Veil, et al., 2011; p. 110). They are not just seeking for information anymore, but also providing it to each other (Palen and Liu, 2007), especially through social media (such as Facebook and Twitter). Citizens as social media users have become an important stakeholder group that needs to be engaged (Pang, et al., 2014). Especially in times of crisis, because authorities can be challenged by citizens (Palttala and Vos, 2011).

In the context of disasters, crisis communication is to prepare people so that they know how to prevent the given crisis from reoccurring as well as to cope with its negative ramifications (Palttala and Vos, 2011). In democratic societies the most fundamental objective of the public sector is to serve citizens (Bowden et al., 2016) and that is also the aim of crisis 
communication. Crisis communication by authorities can contain, for example, warnings and educational messages, as well as evacuation and other instructions (Seeger \& Reynolds 2009).

Thus, the societal purpose of crisis communication is to prevent and reduce harm and damage. It also includes a dialogue on risks and how to recover and learn from the crisis (Palttala \& Vos 2011). Citizens as a stakeholder group is not homogeneous but consists of various smaller groups with different needs and that should be taken into account in order to empower and increase understanding of crises. Citizens' crisis perceptions vary depending on the cause of the crisis and therefore it is crucial to know how people process information they receive (Reich et al., 2011) and the organisation sending it. That is to tailor legitimate crisis messages accordingly and eventually build trust in citizens towards the authority.

\subsection{Social media - a new tool for crisis communication and citizen engagement}

A solid relationship between authorities and citizens is antecedent to understanding their needs, wants, and expectations (Bowden et al., 2016) which is also the precondition for effective crisis communication. Public relations literature describes the ideal relationship between organisations and stakeholders (Ledingham and Bruning, 1998) as two-way and symmetrical (Grunig et al., 2006), and having impact on the economic, social, cultural or political well-being (Ledingham and Bruning, 1998).

The value of public relations is to help organisations build relationships and minimise the possibility of crises (Hung, 2005). Thus, relationship management is seen as a core function of public relations (Cutlip et al., 1994). Ledingham (2003; 190) defines relationship management as "effectively managing organizational-public relationships around common interests and shared goals, which over time, results in mutual understanding and benefit for interacting organizations and publics."

Building relationships can be seen as a long-term plan to engage citizens (Sanders and Canel, 2013). Citizen engagement can be defined as "a form of interactive participation, which aims to involve and/or re-involve citizens in the processes of governance (Bowden et al., 2016; p. 260). Citizen engagement has become important for public sector organisations because they are shifting from "culture of controls" towards citizen satisfaction and participation (Bourgon, 2009). Citizen engagement is in fact a "network of continuous interactions, which, at the most fundamental level, occurs between the public sector organization itself and its citizens, but 
also as the interactions between citizens" (Bowden et al., 2016) as is evident in various online discussions. Related to citizen satisfaction which is vital for public administration in a democratic setting (Thijs \& Staes, 2008), engagement is about understanding not only what governments do, but increasingly about what the end-users need (Sanders \& Canel, 2013).

Social media can be seen as a platform for citizen engagement (Holmes, 2011). It has changed communication, it has moved from monologues given by organisations to dialogues (Capozzi and Zipfel, 2012) with stakeholders. The opportunity to facilitate interaction and two-way communication in social media offers new ways for companies to interact with their customers, and governmental organisations to interact with their citizens (Kavanaugh, et al., 2011). Therefore social media has been seen as a useful tool for crisis communication during different kinds of emergencies and disasters (Taylor et al., 2012).

Public authorities often still perceive social media as another channel for passive dissemination of information (Lindsay, 2011). Social media can be, however, used systematically as part of emergency management. Authorities can give warnings, share information, and monitor user activities in order to improve their situational awareness. It also, for example, can be used to upload visual material to estimate damages (Lindsay, 2011; p. 1; Taylor et al., 2012; Kavanaugh et al., 2011). Social media enables a wide-scale interaction (Sutton et al., 2008) and is a good tool for authorities to receive information on citizens' perceptions, anticipate the rise of issues and problems (Kavanaugh, et al., 2011), and also help people in recovery after a disaster. Social media is also seen to be able to build disaster resilience of communities (Dufty, 2012; Taylor et al., 2012).

However, the majority of information and research in social media is posted by citizens, not authorities (Lindsay, 2011). Nevertheless, with every new disaster the role of social media is "growing as a means for supporting additional, often critical and accurate, dissemination of information within the public sphere" (Sutton et al., 2008; p. 2). Another reason why authorities should be active in social media is that citizens are discussing the crisis anyway, and lack of authority input gives an easy way for disinformation and rumours to spread. The biggest mistake organisations can make is to withhold information so that it starts to leak through unofficial channels and spreads in social media (Korpiola, 2011).

According to Coombs and Holladay (2014) crisis managers have to monitor comments in social media in order to know how organisation is discussed in various sub-arenas of social 
media. They state that citizens can become involved in crisis communication by taking different communicator roles. Citizens can act as: information providers, critics or supporters. Information providers share links to websites, online news sites or first-hand experiences. Critics criticise the organisation or crisis response and supporters, on the contrary, praise it.

Thus, open access social media offers a tool to amplify or attenuate a crisis by publishing accusations or negative comments, or even hoaxes directed at organisations (Veil et al., 2012; 323; Pang et al., 2014) or supporting the organisation (Coombs and Holladay, 2014). Unsatisfied people can use social media to get attention (Haigh and Wigley, 2015) and the so called hate-holders (Author 1) or negatively engaged (Bowden et al., 2016) can challenge organisations or authorities. If a disaster is managed poorly, it may lead to a reputation and credibility crisis. Many organisations are afraid of reputational risks connected to social media and are not willing to open up to the public (Korpiola, 2011). That can be called negative citizen engagement. As citizen engagement is not merely positive, but ranges from negative engagement or disengagement to positive forms, public sector organisations need to constantly monitor and participate in the interaction with citizens (Bowden et al., 2016).

However, not all citizens are critical or negative about authorities. Social media can offer a mechanism for citizens to support the organisation (Veil et al., 2011). Citizens can contribute as "helpers", which was the case during the California wildfires in 2007, when people took pictures and posted them on Twitter with location coordinates to help authorities map the danger area and define scope of the flames' spread. People looked for local information in social media and filled the public information gaps created by lack of authority communication (Sutton et al., 2008). Taylor et al. (2012) studied citizen behaviour in Facebook during a series of natural disasters in Australia and New Zealand in early 2011. According to their results, people seeked news about the course of events, but also asked and answered questions, provided general information, and helped others to find further data. As an outcome, feelings of togetherness and usefulness were reported. However, it is important to know how people react to crisis response, because it indicates whether the chosen communication strategy is accepted or rejected by the target groups (Coombs and Holladay, 2014).

Based on the literature above, the following research questions were proposed: 
RQ1: What issues and what emotions do citizens address on Facebook concerning the Fukushima nuclear accident?

RQ2: What is authority's contribution to the discussion?

\subsection{Challenges of authority crisis communication}

Five dilemmas are introduced in this study that describe the authority-citizen relationship during a crisis. They stem from risk and crisis management and communication literature that scrutinises communication challenges, perception of information, social media and public sector organisations. The five dilemmas are: flexibility of action, arena of communication, knowledge discrepancies, legal constraints, and stigma (see Figure I). They characterise contractions between official communication by authorities and unofficial communication by citizens in social networks.
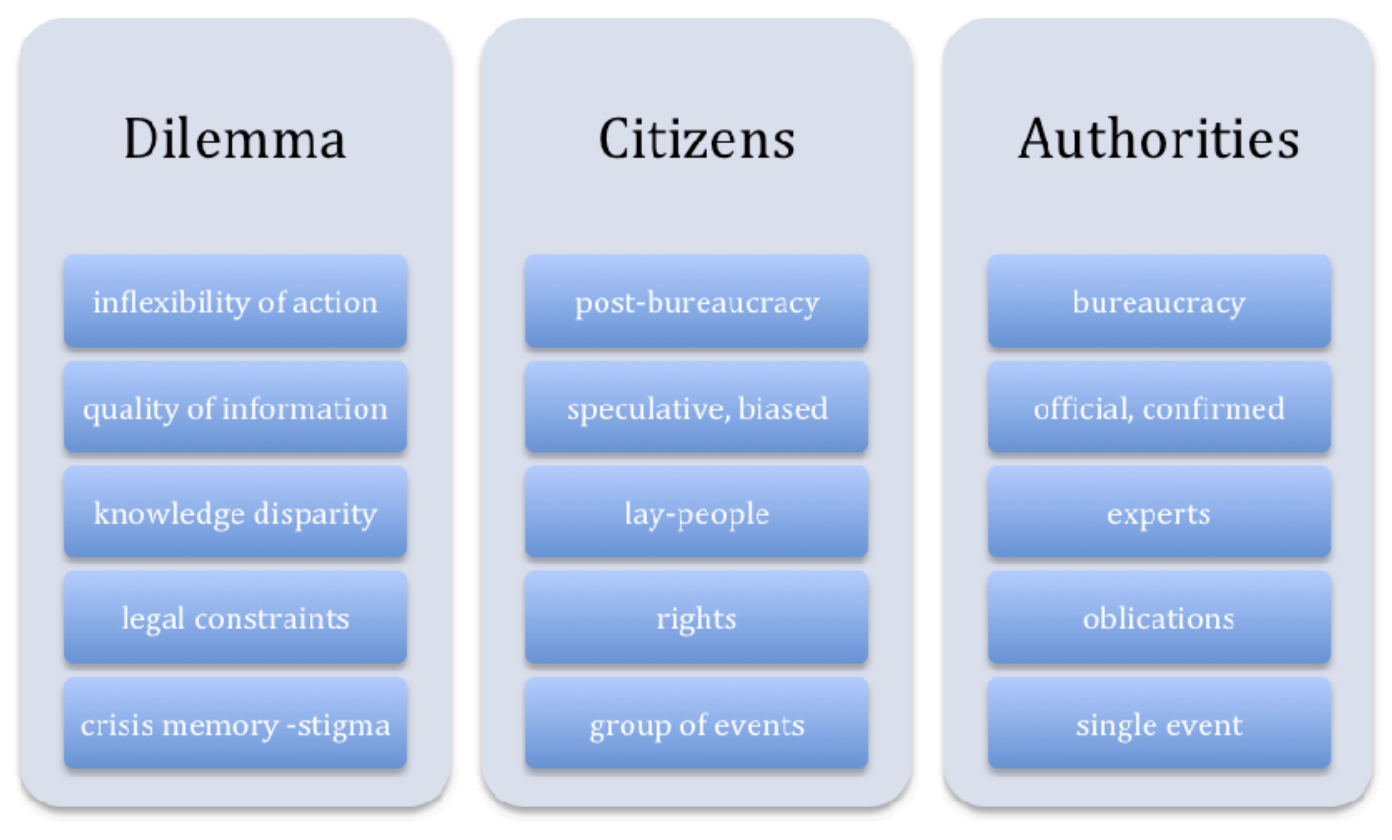

Source: Tirkkonen and Luoma-aho (2014).

The first dilemma, inflexibility of action, means that hierarchical and bureaucratic authority organisations are not able to act and respond as fast as citizens communicate and share information in social media and networks. Authority organisations represent the bureaucratic era with strict division of duties and responsibilities, (Huhtala and Hakala, 2007) whereas networks belong to post-bureaucratic time with their fast-changing, flat, flexible structure, and 
freely flowing information (Castells, 2004). Authorities need to prepare themselves for social media communication in order to systematically use it for crisis communication. Establishing a profile long after the outbreak of a crisis is not reasonable - organisations must be ready to react promptly, both in resources and content (Korpiola, 2011).

Authorities also have difficulties filtering information shared in social media. They do not know their "discussion partners" and whether they are positively or negatively engaged. Identification of these virtual stakeholders is hard, because citizens are not a homogenous group, but include people with diverging opinions and understandings, with different needs and expectations from the authorities (Kavanaugh et al., 2011), often using pseudonyms. In many cases, authorities simply do not have tools to filter the vast amount of information shared in social media (Kavanaugh et al., 2011). Besides, monitored and systematic use of social media requires resources which are often limited.

The second dilemma is the different quality of information citizens and authorities have at their disposal. Citizens share information publicly on social media and construct discussions, having a so-called horizontal dialogue. Peer-distributed information can even be perceived more accurate and up-to-date (Palen et al., 2009; Bowden et al., 2016) than official information from authorities, yet the latter still often perceive peer-to-peer communication as a risk to public safety, which may be the case if misleading and false information is spread online (Sutton et al., 2008). This happened in January 2010 in Manhattan, New York, when rumours started to spread in Twitter and it lead to unnecessary evacuation of the Grand Central Station (Branicki and Agyei, 2014). Citizens can freely share unreliable information and may be biased. They can also make statements and question the legitimacy (Colleoni, 2013) of authorities, if they are not pleased with crisis management and communication (Luoma-aho et al., 2013). However, authorities cannot communicate unconfirmed messages and speculate - all information released must be assured and confirmed first in the private authority arena. That can make authority communication slow.

The third dilemma, disparity of knowledge, refers to authorities as experts of a special field and holders of a wide body of knowledge on a particular topic. In a crisis situation, experts and citizens or lay-people often have diverging perceptions. Citizens' risk perceptions do not necessarily correlate with the "physical danger that the crisis poses to the society, but can be affected by emotions, personal experiences, beliefs, social networks" (Wester Herber, 2004). 
Experts base their judgments on their knowledge and deeper understanding of complex issues, citizens have no other option but to trust or criticise information provided by authorities. Lack of trust diminishes the effectiveness of communication (Seeger, 2006; Slovic, 1999; Coombs and Holladay, 1996). Moreover, once trust is lost, it tends to reinforce and deepen distrust (Slovic, 1999), which affects how people perceive incidents in their living environment. Citizens may also believe that even experts can make mistakes, or overestimate their knowledge and abilities (Sjöberg, 2001). In that case, it is extremely challenging to engage people (Bowden et al., 2016).

The fourth dilemma concerns legal constraints, i.e. citizens' rights and expectations to receive information and authorities' obligations to communicate and protect citizens. A crisis can question authorities' ability to protect (Roux-Dufort, 2007). People tend to look for actors responsible for crises and the higher perceived responsibility, the more they want somebody to carry it (Coombs and Holladay, 2014). Moreover, in a situation of crisis, safety recommendations or even evacuation orders cannot be a topic of discussion or bargaining in order to be fast and effective. In that case, dialogue functions against the authority's role as a commander. An example of unsuccessful authority recommendations was the swine flu vaccination campaign in Finland in 2009. Half of the population did not get vaccinated, because they did not trust or believe the authority communication (Tirkkonen and Luoma-aho, 2011). The pressure put on by citizens or different groups is not necessarily ethical or fair (Theunissen and Wan Noordin, 2012) and places authorities in a difficult situation, as legal constraints restrict them from sharing information freely, and therefore they are not able to publicly argue with citizens.

In other words, an interactive relationship can challenge authority's legal role as a safety provider in the society. That is especially the case if citizens perceive crisis as something that could have been avoided (Coombs, 2007). Authorities are also worried about legitimacy of the information shared during disasters (Sutton, et al., 2008). Therefore, it is reasonable to ask how ready organisations are to open up a true dialogue.

The fifth dilemma involves stigma and stigmatisation. Stigmatisation is a factor that raises hostility and outrage (Lundgren and McMakin, 2013). Stigma refers to "technologies, places, and products that are perceived to be unduly dangerous" (Kasperson et al., 2003; p. 27). For example, the nuclear industry has been publically stigmatised, and as a result, it is almost impossible to find places that would willingly dispose radioactive waste (Slovic, 1999), 
because the stigma is part of the collective memory. The internet and social media can act as "collective memory" where the smallest of incidents are stored and may re-emerge and reactivate in unexpected ways (Author 1 and Author 3). For example, by negatively engaged citizens who may create and spread negative narratives to influence other citizens (Bowden et al., 2016). This poses another challenge to crisis communication, because, in a way, authorities are not only managing the current crisis but also the one in the past, amplified by negatively engaged citizens.

RQ3: How do the five dilemmas characterise the relationship between STUK and active citizens online?

\section{Methods}

This explorative case study attempted to analyse authority-citizen relationship during the Fukushima nuclear disaster. An explorative case study investigates an issue featured by lack of preliminary research (Streb, 2010), and the aim is not to produce information that can be used to generalise or disclose causal relationships, but to gain deeper understanding of a phenomenon or issue (Saaranen-Kauppinen and Puusniekka, 2006). An exploratory case study is characterised by lack of hypotheses (Streb, 2010).

Altogether, 605 Facebook comments were analysed using both quantitative and qualitative content analysis. Content analysis can be defined as "systematic, objective, and quantitative analysis of message characteristics" (Neuendorf, 202; p. 1). In qualitative content analysis, material is classified and similarities and/or differences are pinpointed. Similar expressions and concepts of the same meaning are unified in a class (Tuomi and Sarajärvi 2002, p. 112 113).

All used comments had been posted on STUK's Facebook page during the first two weeks after the nuclear accident in Fukushima Dai-ichi reactor. The first comment is from March 12, 2011, one day after the accident, and soon after STUK had made a Facebook account for the organisation. The last analysed comment dates to March 27, so the analysed period encompasses exactly the two weeks after first news from Japan reached Europe. The twoweek period was chosen because it was the most hectic period of crisis for the particular Finnish authority. 
All comments were coded into an Excel sheet designed beforehand. Additionally, a codebook explaining all the codes was created. While coding the comments, the following variables were scrutinised (see table II): date, person's name, nature of the comment, topic of the comment, tone towards the authority, number of likes and links, and a description of the content of the comment that was later used in the qualitative analysis. The variables derive from the coding book of Huhtala and Hakala's (2007) study of a tsunami in Thailand in 2004, as well as from the research questions determined earlier.

\begin{tabular}{|c|c|}
\hline Day & Date when the comment was posted \\
\hline Commentator & $1=$ STUK, $2=$ citizen, $3=$ group or organisation \\
\hline Name & Name of the commentator \\
\hline Likes & Number of likes \\
\hline Nature of the comment & $\begin{array}{l}\text { 1=providing information, } 2=\text { giving advise, } 3=\text { asking } \\
\text { question(s), } 4=\text { asking for help, } 5=\text { giving a statement, } \\
6=\text { telling his/her opinion, } 7=\text { irrelevant }\end{array}$ \\
\hline Topic of the comment & $\begin{array}{l}1=\text { describing course of events, } 2=\text { rescue work in Japan, } \\
3=\text { development of the situation in Japan, } 4=\text { Finnish } \\
\text { authorities and their actions, } 5=\text { Media coverage, } \\
6=\text { victims, casualties, } 7=\text { standing for/against something } \\
\text { (for/against nuclear energy) }\end{array}$ \\
\hline Content of the comment & Written down for qualitative analysis \\
\hline $\begin{array}{l}\text { Tonality towards the } \\
\text { authorities }\end{array}$ & $1=$ neutral, $2=$ negative, $3=$ positive, $4=$ not clear \\
\hline $\begin{array}{l}\text { Links (if the comment } \\
\text { contained URL) }\end{array}$ & $\begin{array}{l}1=\text { media, } 2=\text { authorities, } 3=\text { against nuclear energy sites, } \\
4=\mathrm{NGO}, 5=\text { campaign site, } 6=\text { personal blog, } 7=\text { social } \\
\text { media, } 8=\text { scientific source, } 9=\text { book or another written } \\
\text { source, } 10=\text { acts of law, } 11=\text { unclear }\end{array}$ \\
\hline URL & Link copied \\
\hline
\end{tabular}

Table I. Coding variables of the study.

All the categories and variables were mutually exclusive, meaning that only one option could be chosen to determine the comment analysed. Every category was given a number so that the information retrieved from postings was transformed into a numerical form. After coding the comments one by one, the pivot function on Excel was used for statistical analysis.

The variable content of the comments was not numerically coded during the first round of analysis, qualitative thematic coding was used instead. Quantitative coding showed that only 24 people posted more than six comments during the two weeks. Altogether there were 273 comments $(\mathrm{N}=605)$ that were first coded by categorising them according to emotions expressed towards authorities: neutral, positive or negative. Then, the comments were 
analysed again and divided into subcategories that were later named as different participator profiles.

Neutral comments did not contain any expression of positive or negative emotions towards authorities (text in square brackets is added by the authors):

"Check the website of Helsingin Sanomat (the biggest daily newspaper in Finland), there you will find information step by step.” [Person shares a link to the newspaper homepage - Information provider]

"If you are interested in up-to-date information, I recommend you to read instructions given by the senior researcher of VTT (Technical Research Centre of Finland)." [Person shares link to the Facebook page of Embassy of Finland in Tokyo where the instructions were published - Information provider]

"Can radiation reach us in Bangkok as well?" [Worrywart]

"Do you believe [referring to STUK] that there is a completely safe nuclear power plant? Have you considered all the possible natural disasters that could happen in the future?" [Worrywart]

"Is it so that whatever happens in Fukushima, there is no danger [of radiation] in Finland? [Worrywart]

Negative comments contained clear elements of unsatisfied or displeased expressions towards authorities or hinted at possible vested interests, conspiracies, or clearly biased beliefs.

"How can STUK handle crisis communication if something happens in Finland [official websitestuk.fi crashed]? Website has been replaced already by an information site [referts to the simple version of STUK's homepage]." [Sceptic]

"You have given a comment that there could be a local radiation fallout in Fukushima that could be compared with the fallout in Chernobyl. Is the comment based on facts, or is it only speculation?... I think STUK shouldn't intimidate people in vain." [Sceptic]

"I don't believe that STUK's website just crashed...the big bosses are deciding what to do." [Scaremonger]

"Eat onions and other natural stuff. You can get cancer by eating iodine tablets." [Scaremonger]

Positive comments contained positive, satisfied or supportive messages:

"I like this. When foreign authorities cannot or do not want to provide credible information, you will gather it yourself. Well done STUK! [Authority defender]

"Remember to take a rest there" [Authority defender]

All the comments on the page were written in Finnish and translated into English by the authors, therefore there might be small differences due to translation. 


\section{Results}

The goal of the study was to investigate authority communication and relations to citizens during the Fukushima nuclear disaster in the Finnish context. Altogether, 605 comments were posted on Facebook within two weeks after the earthquake and tsunami in Japan that caused serious damage to the Fukushima Dai-ichi nuclear reactors. A total of 155 different people or pseudonyms wrote on STUK's Facebook page and made an average of 3.9 comments. There were 24 people who were more active in posting, writing more than 6 comments. Out of that subgroup, 10 people wrote more than 10 comments; 24 comments by one person being the maximum during the two weeks. Thus, the majority of the people wrote only one to three comments, and cannot be seen as active participants in the discussion.

Several different people replied to comments on behalf of STUK, but one person wrote more than half $(52 \%)$ of the total of 89 comments. Authority representatives used their first name as identification. The communications department did not write all of STUK's comments; experts working at STUK answered questions as well. There were 147 different posts on the topic on STUK's page where people left their comments; 97 discussions were initiated by citizens and 50 by authorities. Authorities participated in 26 discussions initiated by citizens, which means that altogether almost half of the discussions (48.2\%) were held only between citizens. The rest of the discussions were started by groups or pseudonyms referring to groups - Greenpeace Finland, 'Nuclear energy belongs to the past', and 'Nuclear disaster in Japan $2011^{\prime}$

The plurality of comments, $25.7 \%$ of the total, were about the situation in Japan (156 comments), the second largest concern was how the accident affected nature and humans $17.8 \%(108)$, and the third major issue was the safety of nuclear industry, which collected $16.6 \%$ (101) of the comments. The quality and content of authority communication became the fourth largest topic (15.7\%, 95 comments). Technical problems, mostly revolving around STUK's homepage and real-time press conferences, was the fifth most popular $(11.6 \%, 70)$, and rescue operations - what has been done and what are the plans, collected $8.9 \%$ of the total comments (54). 


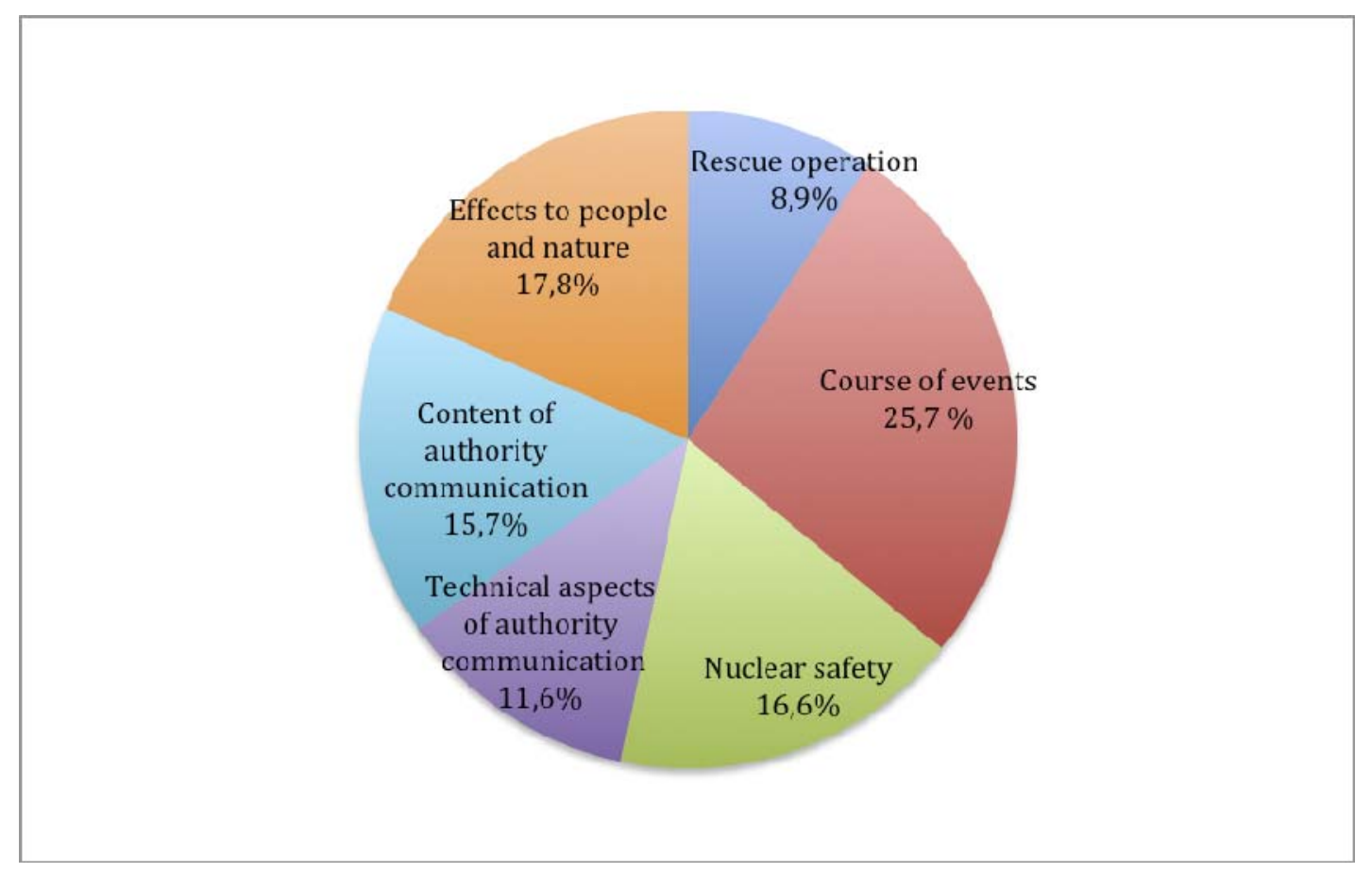

Figure 2. Topics of the comments

The reasons why people wrote on the Facebook page could not be determined by comments alone, but at first glance, their aim was to share information, answer people's questions, and ask questions or express their opinion. STUK was not the only one answering people's queries - co-citizens also actively provided answers and shared their opinions, either supporting or arguing statements of others. 


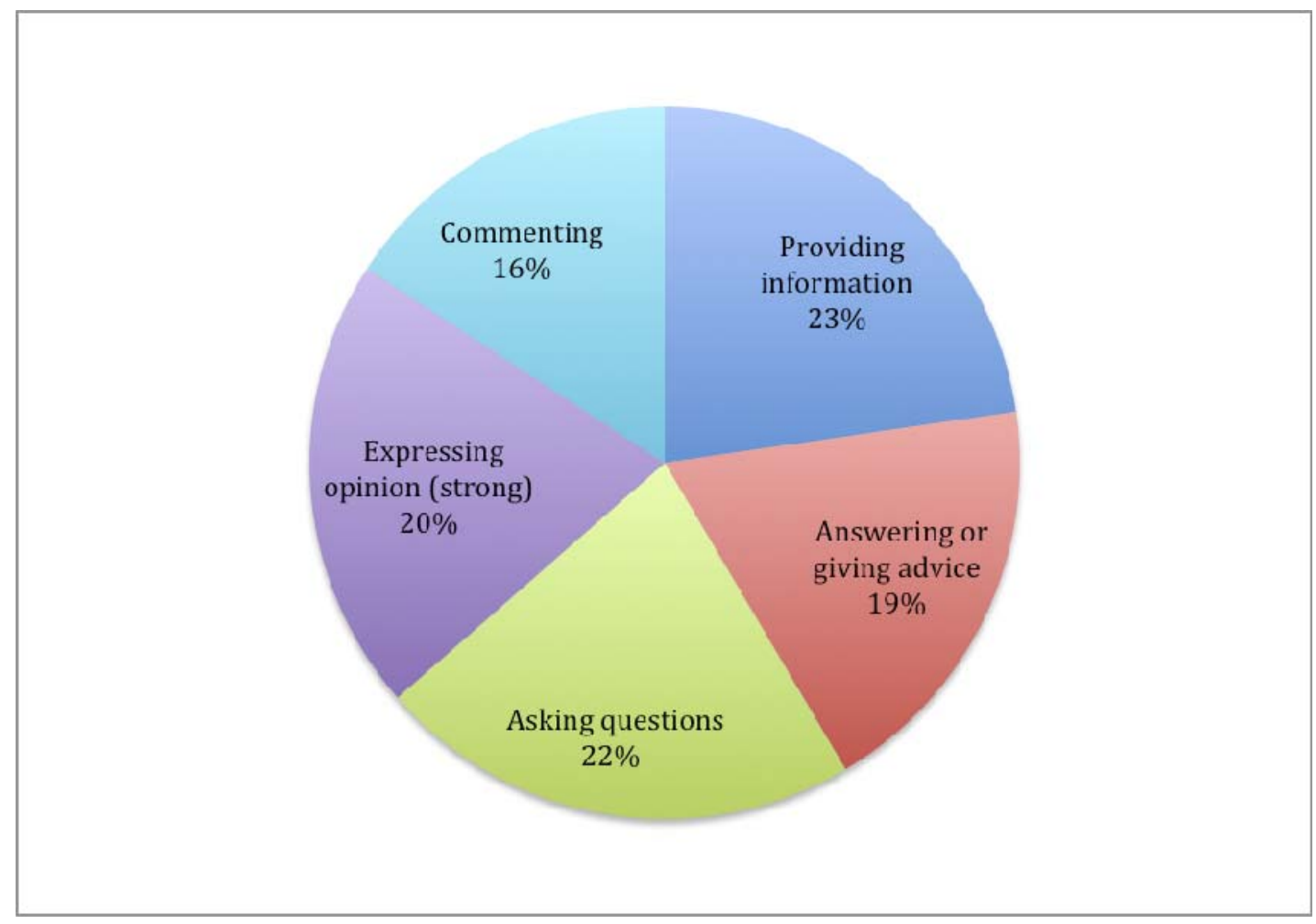

Figure 3. Nature of the citizens' comments

Most people who provided information shared links to national and international media reports on the catastrophe and course of events. They also posted instructions on how to protect yourself from radiation and how it affects humans, animals, and agriculture in general. Plus, they shared information about Finns living or travelling in Japan, and commented on the radiation levels in Finland, as well as supplied technical information about devices and offer solutions to how the situation in the reactors could be stabilised.

\subsection{Participator profiles}

After analysing the comments of the most active participators, it can be said that citizen engagement overall was low, as most of the people or pseudonyms wrote only one to three comments on the Facebook page. Altogether, 24 people wrote 52\% (273) of all citizen comments (total amount of citizen comments, 516). Based on qualitative analysis of the content and nature of the comments, the following five participation profiles were formed: Information and Aid Providers, Worrywarts, Sceptics, Scaremongers, and Authority Defenders. All the comments were thematically coded into different categories according to the content of the comment. 


\section{1) Information and Aid Providers}

Those were people willing to share links, data and information about the situation. Links and data shares varied from trustworthy sources like big international media websites (e.g., New York Times, Reuters) to individual and newspaper blogs and authority websites (e.g., the Finnish Ministry of Foreign Affairs, the International Atomic Energy Agency, or IAEA). People also wanted to provide aid for authorities by suggesting different solutions on how to organise rescue work on the scene. Commentators did not seem to hold any specific expertise or worldview, but comments were based on their "common sense" with some comments challenging the authorities' decisions.

"Why don't you suggest that they would bring tugboats to the shore with big fire pumps on them? The fire pumps could be connected to fire hoses." (An Aid Provider who commented on rescue work in Dai-ichi)

"Through this link you will find information on weather and flood situation." (Shared a link to the joint website of Finland's environmental administration.)

"TepcoDisaster writes on Twitter: Power cable to the Fukushima Dai-ichi no 1 is connected."

\section{2) Askers and "Worrywarts"}

This group of comments comprised mostly of questions about travelling recommendations and safety, about the situation in Dai-ichi and the seriousness of the accident. People were wondering why Japanese authorities were acting so slowly, what kind of reactor type Dai-ichi had, why the cooling system did not work, and how serious the accident was compared to Chernobyl. Questions about food safety, radiation levels in Finland, and the country's preparedness were asked as well. Most of the questions were about the radioactive leak, halflife of different radioisotopes, ramifications to nature and people.

"Is it true that according to a representative of STUK, the situation in Japan is worse than the Chernobyl nuclear accident in $1986 ? "$

"Can I buy clothes and shoes from the US West Coast without any risk of contamination?"

\section{3) Sceptics}


Sceptics strongly questioned Finland's preparedness for a similar disaster. They were also dubious about authority information, their expertise and capability to cope. They eagerly followed regularly published radiation numbers. Sceptics criticized STUK's technical problems with communication, such as the crash of their website, triggered by a big number of page visitors. They were also critical towards STUK's director, basing their criticism on director and deputy director's comments in the media, and argued with Authority Defenders as well.

\footnotetext{
"This is only the foretaste of what would happen, if an accident took place in our neighbouring areas. If this situation cannot be managed, one can only imagine the number of visitors to the website, if an accident would be located near us..." (A Sceptic commenting on the crash of STUK's website)
}

"I think STUK should not create panic on purpose by giving statements without facts. It is weird that an authority starts to publicly speculate about potential risks instead of sharing factual information. This interview was shared by STT (Finnish news agency). Was it originally in STUK's press release? (A Sceptic commenting on news spreading in mass media where a representative of STUK commented that the possible nuclear fallout in Japan can be bigger than in Chernobyl)

\section{4) Scaremongers}

Spreading information about how bad is the situation, reminding people that they should open their eyes and not believe messages communicated by the authorities. Their comments also hinted that the nuclear industry is far more dangerous than authorities are ready to admit, and that community will suffer from the decisions "important and powerful people" make. Scaremongers also seemed to give credence to conspiracy theories.

\footnotetext{
"If they (authorities) were honest about these issues, citizens would feel better." (A Scaremonger commenting on authorities' communication)

"We should question all the official information that is given to us, as well as unofficial. The fact is that this nuclear accident in Japan is many times bigger than Chernobyl. I really wonder why authorities are saying that it does not affect Finland - of course it does." (A Scaremonger questioning the credibility of information given by authorities)
}

\section{5) Authority Defenders}

People who were trying to calm down those who criticised authorities' behaviour and seemed to believe in conspiracy theories. Authority Defenders were also sharing information and explaining the complexity of the situation to people, sometimes by using well-reasoned arguments with a clear knowledge of physics. Pro-nuclear attitudes were visible in the 
comments. One Authority Defender shared information and instructions on iodine tablets, for example. Aid Providers (see profile 1) did not seem to have any deeper understanding about the authorities' role or of nuclear physics that deputy authorities seem to hold. One person openly said that they had been working for STUK and that her spouse was still a member of the organisation.

"I like this. When foreign authorities or media cannot or do not want to provide trustworthy information, we will find it ourselves. Well done STUK!” (An Authority Defender commenting on STUK's radiation measurements from Tokyo airport)

"More information about the availability of iodine tablets on the website of Finnish Embassy in Japan...Do you $\mathrm{X}$ have scientific proof of the connection between cancer and iodine tablets?"

(An Authority Defender on sharing information about iodine tablets and arguing with a Scaremonger, who said iodine tablets are causing cancer)

So, the discussion was held between these different profiles and authorities. When Sceptics criticised authority communications and actions, or Worrywarts asked their questions, Authority Defenders joined the discussion by giving their opinions and counter-statements. They also answered part of the questions instead of the authorities. Information Providers contributed to the interaction by continuing to share news about the course of events. Scaremongers' agenda seemed to be to inform people of a conspiracy and the vested interest of powerful leaders behind events.

It must be stated that these five profiles are not necessarily attached to certain people, so that one person would solely represent only one profile. For example, some people wrote comments by referring to an existing conspiracy, by asking questions about the rescue work, and by sharing information and links to different media channels. However, profiles of Authority Defenders, Sceptics and Scaremongers were clear. One person or pseudonym represented one of the profiles, so either pro or anti-authority group.

\subsection{Authority response}

Authority representatives participated actively in the discussion during the first two weeks after the outbreak of the crisis. During that time, a total of 149 different discussions were started and STUK participated in 76 of them. STUK members posted a total of 89 comments, most were written by the communication department, but specialists also took part. Authority comments can be divided into two categories: information sharing and answers to questions. 
STUK organised several press conferences and citizens could follow them online through links published on Facebook. Information about the press releases, situation updates, and Finnish authorities' and IAEA's recommendations were published as well. The second group of postings answered citizens' concerns about the situation in Dai-ichi, the ramifications of the meltdown of three reactors, the health impact of radiation, and questions about the reactor type, its cooling system, and safety issues in general.

STUK was unable to answer all of the citizens' questions, and on one occasion they stated that they were lacking resources to answer all the posted questions. Some of the answers were fairly technical and therefore potentially difficult to understand by people without background information or knowledge about nuclear energy and technology.

"The maximum amount of radiation for people working in nuclear power plants is 50000 microsieverts or 100 000 microsieverts during five years."

“...radiation is still high, approximately 2000 microsieverts per hour."

The majority of Authority comments (56\%) provided new information about the course of events in Japan by linking to a press release or a link to another authority's website. Therefore STUK used the Facebook page as a channel for one-way communication, as is typical for media relations, in order to inform citizens. Other comments were participative in their nature, by entering a discussion started by a citizen on STUK's page. In one comment, the organisation recommended people to follow its website and Twitter, instead of Facebook, because they did not have enough resources to be active in all the channels.

The commenting style of all authority posts was neutral, and information was provided regularly. When authorities got positive feedback, STUK either did not react or thanked for the feedback. When it comes to critics, they either remained silent or wrote a neutral comment about whether the criticism was about technical problems with the website, press conference streaming, about information people questioned, or STUK's comments in media that people criticised. There were no signs of getting provoked by the Sceptics or the Scaremongers.

Authority comments caused a mix of neutral, positive, and negative reactions, as suggested in the participator profiles. When authorities started a new discussion by providing information, citizens did not react to 23 of those postings. Proactive communication got positive feedback. Only two of STUK's posts caused clearly negative reactions right after they were published. 
One of those posts was about the statements given by the deputy director, which were perceived as arrogant and the other one about carrying out safety assessments in Finnish nuclear power plants. Assessments were perceived as an insufficient measure to guarantee safety and comments reflected disbelief towards authority.

\section{Discussion}

The aim of this thesis was to shed light on the authority-citizen relationship during the Fukushima nuclear disaster by answering the following questions: what issues and emotions did citizens address about the Fukushima nuclear accident, what was the authority contribution to the discussion, and how do the five dilemmas stemming from the literature characterise the relationship between STUK and citizens active online.

The discussion on STUK's Facebook page was a good example of chatting citizens, who clearly made sense of the situation (Reynolds and Seeger, 2005) and were part of crisis communication (Veil et al. 2011) by not just seeking information, but also providing it to each other (Palen and Liu, 2007). They mostly commented on the overall situation in Japan, pondered how the accident affected nature and humans, and the safety of the process of nuclear energy production. Authority communication was also actively commented upon. It can be said that citizens were an active part of crisis communication like Veil, Buehner and Palenchar (2011) claim.

Results also showed that citizens perceived the disaster differently as stated by Reich et al., (2011) and Coombs and Holladay (2014). According to the five participant profiles formed, people were looking for information, asking questions, answering them, and simultaneously expressing their own opinions about the course of events. It became evident that part of the commentators wanted to express their disbelief towards authorities' actions and communication, as well as their capability to protect citizens and manage a similar kind of a crisis had it taken place somewhere in Finland. A separate profile was made for people who believed conspiracy and attacked the use of nuclear energy.

Sutton et al. (2008) and Veil et al. (2011) state that citizens can act as "helpers" in a crisis. There were a group of authority defenders or faith-holders (Luoma-aho, 2015), who justified authorities' actions, their expertise and also tried to clarify the situation to other participants. Next to them there were a group of hate-holders (Author 1) or negatively engaged citizens 
(Bowden et al., 2016) that remained disapproving of authority's communication and competence as well as made accusations, such as Veil et al. (2012) and Pang et al. (2014) emphasise. Thus, the results support Coombs and Holladay's (2014) categories of citizens as crisis communicators, information providers, critics and supporters.

The most fundamental objective of public sector is to serve citizens (Bowden et al., 2016). Due to shift from "culture of controls" to citizen satisfaction and participation, citizen engagement has become an important part of organisations' agenda (Bourgon, 2009). That calls for relationship building (Ledingham and Bruning, 1998) and two-way communication (Grunig et al., 2006). Citizens were active by posting over 605 comments during two weeks, but authority response could have been more proactive. Almost half of the discussions $(48,2$ $\%)$ were held between citizens.

The aim of authority crisis communication is to help people to contribute to preventing such events as well as coping with its ramifications (Palttala and Vos, 2011). In this case, communication was not so much about coping with ramifications, but about providing information on the situation in Dai-ichi because Finns were not in physical danger. However, STUK could have tried to explain the situation better by providing more resources to actively participate in discussions. Social media offers new ways for interaction (Kavanaugh et al., 2011) and is also a good tool for monitoring citizens' crisis perceptions (Taylor et al., 2012). Thus, authority representatives should have noticed the anxiety of citizens, who did not get an exhaustive answer to their question and therefore had room for speculation. They could also have explained in more detail the negatively perceived deputy director's statements as well as the safety assessments run in Finnish nuclear power plants.

Instead of consistently answering citizens' questions, most of the 89 comments STUK posted concentrated on providing information by sharing links to press releases they had sent to mass media. Results support Lindsay's (2011) claim that public authorities still perceive social media as just another channel of passive dissemination of information. Therefore, their use of social media can be called as relatively passive information-sharing and not aiming at relationship-building or citizen engagement, for example, by asking questions or addressing not only technical aspects of the crisis, but also people's worries. This can be explained by the fact that the organisation had just opened the Facebook account right after the outbreak of the disaster and did not have enough resources to answer all the questions, which STUK also 
admitted. Like Korpiola (2011) claims, interaction with stakeholders should start before crisis so that the organisation could be well prepared.

When it comes to the five dilemmas introduced in this study, they were all notable in the social media discussion. The dilemma of inflexibility of action, for example, was visible, when STUK as a bureaucratic organisation was not able to answer all citizens' questions, or replied several hours later. Authority representatives admitted that they did not have enough resources to respond to every query on Facebook. They also did not seem to participate as a separate different stakeholder type, but answered and communicated at all times with the same informative style.

Slow reactions and lack of resources brought up the second dilemma, quality of information. Social media is a new tool for crisis communication, not only because it offers a possibility for discussion, but also because citizens and authorities use it differently. Citizens tend to trust horizontal rather than vertical engagement (Bowden et al., 2016). Social media is all about peer-distributed information that can be perceived as more accurate than official authority messages (Palen et al., 2009) although being biased. The more authority is able to participate in the discussion, the easier it is to prevent false information from spreading online, which is perceived as a risk for public safety (Sutton et al., 2008). However, requirement for official and confirmed information can make authority communication slow.

The third dilemma, the disparity of knowledge between authority and citizens was very evident. According to Wester Herber (2004) the 'expert - lay people' difference can hamper crisis communication. Citizens may not understand the information authorities give out, or like Sjöberg (2001) stated, they may think that experts can make mistakes and overestimate their knowledge. This disparity was visible in the comments where representatives of STUK with expert knowledge tried to explain the nature of radiation, the difference between radioisotopes, their behaviour and effects, and the technical system of nuclear power plants, but the sceptic public kept asking the same questions. Based on our results, it can be stated that authorities had difficulty in convincing people, which according to Coombs and Holladay (1996) can diminish the effectiveness of communication. Sjöberg (2001) states that citizens may believe authorities overestimate their knowledge and abilities. The Sceptics and Scaremongers did not understand STUK's answers, or did not want to believe them and reacted negatively to the information, especially to the comments on safety issues of nuclear 
energy industry. Obviously, these two groups of citizens were not convinced in what authority said.

The dilemma of obligations versus rights, i.e. the legal constraints that authorities face, was not so visible in the discussion, because STUK's crisis communication did not contain any orders that citizens should have followed, since the accident did not put Finns in physical danger. However, it can be said that the dilemma would have become visible if the accident had happened nearby. Some citizens were questioning the authorities' ability to manage such crises, just as Roux-Dufort (2007) explains. Preparation plans and safety issues were also widely discussed and part of comments showed worry about how Finland would survive a similar disaster. Contrary to the Sceptics and Scaremongers, the Authority Defenders expressed support for authorities' actions, helped to explain technical details of nuclear power plants and nuclear energy, shared official information, and also tried to calm down worrying people.

The fifth dilemma of "stigma" prevailed right from the beginning of the Facebook discussion. Luoma-aho and Vos (2010) state social media can be a "collective memory" where incidents are stored and activated in unexpected ways. Results show that the stigma that nuclear industry has in the minds of the public, mostly because of the Chernobyl catastrophe in 1986, still affects people's crisis perceptions. Like Renn (2008), Slovic (1999) and Coombs (2007) state, crises have a history of their own, and Fukushima can be said to be one episode in the nuclear energy crisis. People who were worried and sceptical about how the authorities had dealt with the Ukrainian accident let that affect their perception of the Fukushima crisis as well.

\section{Conclusions}

From this study, it can be concluded that people who participate in online discussions have deeply rooted ideas and views of their own that influence how they see and react to a certain crisis. They can be supportive, negative or neutral - from Authority defenders to Scaremongers and Information providers to Worrywarts.

People with pro or anti-authority attitudes stuck to their opinion and did not express any alteration; the discussion was a collision of different perceptions and the Facebook page 
served mainly as an arena of self-expression. Authority was part of the discussion, but its contribution was more providing information than having an active discussion with citizens. Kavanaugh et al. (2011) claim that social media is not a channel for one-way information sharing but a tool for monitoring and mapping how and what different stakeholders think by having a direct contact with them. In a crisis situation where people's lives are in danger or there are other risks, social media can also be a tool to engage people, motivate action, and help authorities keep citizens safe (Taylor et al., 2012; Kavanaugh et al., 2011.)

The study also presents several dilemmas that may hamper effective crisis communication. Some stemming from knowledge discrepancy between authorities and citizens, some from the fact that social media is a part of networked society, where information flows extremely fast and horizontal interaction is perceived more relevant than vertical communication between authorities and citizens. In those circumstances, bureaucratic and inflexible organisations face challenges in keeping up with the speed of communication while having limited resources and time at their disposal.

Another factor authorities need to consider is crisis history. Internet and social media act as a sort of collective memory that can easily be activated and negative connotations from negative memories can be added to discussions (Luoma-aho and Vos, 2010). Also, discussions in social media are uncontrollable and positive, neutral, critical and even hostile comments are available simultaneously. Different participant profiles and their needs must be addressed differently, preferably with tailored messages. In order to do that, authorities need resources and time, which often lacks. If nothing else, authority participation is necessary to prevent false information from spreading.

Our contribution to crisis communication field lays in mapping the different online participator profiles and also in analysing stakeholder reactions to authority crisis communication. We can claim that organisations should consider these different stakeholders when planning crisis communication, because they help to understand how different citizens perceive crises and it makes producing tailored messages easier.

Because the study was based on a single case study, further investigation of the proposed participator profiles needs to be made to validate these findings. Future research could include a larger number of crises where authorities have been active in social media and participated in discussions with citizens. Researchers should also study how citizens representing the five 
different participator profiles feel about the discussion, and what are their motives for participation. Moreover, it is crucial to know how hate-holders or negatively engaged people can be affected so that they could shift the profile to faith-holders and vice versa - how a faith-holder can become a hate-holder. Information is required so that national authorities can assist citizens of their countries and anticipate what a crisis - such as the Fukushima disaster can mean communication-wise.

\section{References}

Bourgon, J. (2009), "New directions in public administration: serving beyond the predictable", Public Policy and Administration, Vol. 24 No. 3, pp. 309-330.

Bowden, J.L.-H., Luoma-aho, V. and Naumann, K. (2016), "Developing a spectrum of positive to negatiive citizen engagement", in Brodie, R.J., Hollebeek, L. and Conduit, J. (Eds), Customer Engagement. Contemporary Issues and Challenges, Routledge, New York, NY, pp. 257-277.

Branicki, L.J. and Agyei, D.A. (2014), "Unpacking the impacts of social media upon crisis communication and city evacuation", in Preston, M., Binner, J.M., Branicki, L., Galla, T., Jones, N., King, J., Kolokitha, M. and Smyrnakis, M. (Eds), City Evacuations: An Interdisciplinary Approach, Springer, Berlin and Heidelberg, pp. 21-37.

Capozzi, L. and Zipfel, L. (2012), "The conversation age: the opportunity for public relations", Corporate Communications: An International Journal, Vol. 17 No. 3, pp. 336-349.

Castells, M. (2000), "Materials for an exploratory theory of the network society", British Journal of Sociology, Vol. 51 No. 1, pp. 5-24.

Castells, M. (2004), "Informationalism, networks, and the network society: a theoretical blueprint", in Castells, M. (Ed.), The Network Society. A Cross-Cultural Perspective, Edward Elgar Publishing Ltd, Cheltenham, pp. 3-48.

Castells, M. (2013), Communication Power, 2nd ed., Oxford University Press, New York, NY.

Colleoni, E. (2013), "CSR communication strategies for organisational legitimacy in social media", Corporate Communications: An International Journal, Vol. 18 No. 2, pp. 228-248.

Downloaded by Tallinn University At 10:20 23 October 2016 (PT)

Coombs, W.T. (2007), "Protecting organisation reputations during a crisis: the development and application of situational communication theory", Corporate Reputation Review, Vol. 10 No. 3, pp. 163-176.

Coombs, W.T. (2014), Ongoing Crisis Communication. Planning, Managing, and Responding, 4th ed., Sage Publications, Thousand Oaks, CA. 
Coombs, W.T. and Holladay, S.J. (1996), "Communication and attributions in a crisis: an experimental study of crisis communication", Journal of Public Relations Research, 431 Vol. 8 No. 4, pp. 279-295.

Coombs, W.T. and Holladay, S.J. (2014), "How publics react to crisis communication efforts", Journal of Communication Management, Vol. 18 No. 1, pp. 40-57.

Cutlip, S.M., Center, A.H. and Broom, G.M. (1994), Effective Public Relations, 7th ed., Prentice-Hall International, London.

Dufty, N. (2012), "Using social media to build community disaster resilience", The Australian Journal of Emergency Management, Vol. 27 No. 1, pp. 40-45.

Grunig, J.E., Grunig, L.A. and Dozier, D.M. (2006), "The excellence theory”, in Botan, C.H. and Hazleton, V. (Eds), Public Relations Theory II, Lawrence Erlbaum Associates, Inc., New York, NY, pp. 19-54.

Haigh, M.M. and Wigley, S. (2015), "Examining the impact of negative, user-generated content on stakeholders", Corporate Communications: An International Journal, Vol. 20 No. 1 , pp. 63-75.

Holmes, B. (2011), "Citizens' engagement in policymaking and the design of public services", Research Paper No. 1, 2011-2012, Parliament of Australia Department of Parliamentary Services, Canberra, available at: www.aph.gov.au/About_Parliament/Parliamentary_Departments/Parliamentary_Library/pubs/ rp/rp1112/12rp01 (accessed 5 March 2016).

Huhtala, H. and Hakala, S. (2007), Kriisi ja viestintä, Gaudeamus, Helsinki.

Hung, C. (2005), "Exploring types of organisation-public relationships and their implication for relationship management in public relations", Journal of Public Relations Research, Vol. 17 No. 4, pp. 393-426.

Kasperson, R.E., Kasperson, J.X., Pidgeon, N. and Slovic, P. (2003), "The social amplification of risk: assessing fifteen years of research and theory", in Pidgeon, N., Kasperson, R.E. and Slovic, P. (Eds), Social Amplification of Risk, Cambridge University Press, Cambridge, pp. 13-46.

Kavanaugh, A., Fox, E.A., Sheetz, S., Yang, S., Li, L.T., Whalen, T., Shoemaker, D., Natsev, P. and Xie, L. (2011), "Social media use by government: from the routine to the critical", Proceedings of the 12th Annual International Digital Government Research Conference: Digital Government Innovation in Challenging Times, ACM, New York, NY, pp. 121-130.

Korpiola, L. (2011), Kriisiviestintä digitaalisessa julkisuudessa, Infor Oy, Kuopio.

Ledingham, J. (2003), "Explicating relationship management as a general theory of public relations", Journal of Public Relations Research, Vol. 15 No. 2, pp. 181-198. 
Ledingham, J. and Bruning, S. (1998), "Relationship management in public relations: dimensions of an organisation-public relationship", Public Relations Review, Vol. 24 No. 1, pp. 55-65.

Lindsay, B.R. (2011), "Social media and disasters: current uses, future options, and policy considerations", CRS report for Congress, Washington, DC, available at: www.fas.org/sgp/ crs/homesec/R41987.pdf (accessed 21 July 2015).

Lundgren, R.E. and McMakin, A.H. (2013), Risk Communication. A Handbook for Communicating Environmental, Safety, and Health Risks, 5th ed., Wiley \& Sons, New Jersey, NJ. Downloaded by Tallinn University At 10:20 23 October 2016

Luoma-aho, V. (2015), "Understanding stakeholder engagement: faith-holders, hateholders \& fakeholders", Research Journal of the Insitute for Public Relations, Vol. 2 No. 1, pp. 1-28, available at: www.instituteforpr.org/understanding-stakeholder-engagement-faith-holdershateholders-fakeholders/ (accessed 18 August 2015).

Luoma-aho, V. and Vos, M. (2010), "Towards a more dynamic stakeholder model: acknowledging multiple issue arenas", Corporate Communications: An International Journal, Vol. 15 No. 3, pp. 315-331.

Luoma-aho, V., Tirkkonen, P. and Vos, M. (2013), "Monitoring the issues arenas of the swine flu discussion”, Journal of Communication Management, Vol. 17 No. 3, pp. 239-251.

Neuendorf, K.A. (2002), The Content Analysis Guidebook, Sage Publications, Thousand Oaks, CA. Palen, L. and Liu, S.B. (2007), "Citizen communications in crisis: anticipating a future of ICT-supported public participation", CHI Proceedings - Emergency Action, pp. 727-736.

Palen, L., Vieweg, S., Liu, S.B. and Hughes, A.L. (2009), "Crisis in a networked world. features of computer-mediated communication in the 16 april 2007, virginia tech event", Social Science Computer Review, Vol. 27 No. 4, pp. 467-480.

Palttala, P. and Vos, M. (2011), “The crisis communication scorecard: supporting emergency management by authorities", in Vos, M., Lund, R., Reich, Z. and Harro-Loit, H. (Eds), Developing a Crisis Communication Scorecard. Outcomes of an International Research Project 2008-2011, Jyväskylä Studies in Humanities 152, Jyväskylä University Press, Jyväskylä, pp. 15-48.

Pang, A., Hassan, N.B.B.A. and Chong, A.C.Y. (2014), "Negotiating crisis in the social media environment", Corporate Communications: An International Journal, Vol. 19 No. 1, pp. 96-118.

Reich, Z., Bentman, M. and Jackman, O. (2011), "A crisis communication guide for public organisations", in Vos, M., Lund, R., Reich, Z. and Harro-Loit, H. (Eds), Developing a Crisis Communication Scorecard. Outcomes of an International Research Project 2008-2011, Jyväskylä Studies in Humanities 152, Jyväskylä University Press, Jyväskylä, pp. 265-324.

Renn, O. (2008), Risk Governance. Coping with Uncertainly in a Complex World, Earthscan, London. 
Reynolds, B. and Seeger, M.W. (2005), "Crisis and emergency risk communication as an integrative model", Journal of Health Communication, Vol. 10 No. 1, pp. 43-55.

Roux-Dufort, J. (2007), "Is crisis management (only) a management of exceptions?", Journal of Contingencies and Crisis Management, Vol. 15 No. 2, pp. 105-114.

Saaranen-Kauppinen, A. and Puusniekka, A. (2006), "KvaliMOTV - Menetelmäopetuksen tietovaranto", Yhteiskuntatieteellinen tietoarkisto, available at: www.fsd.uta. fi/menetelmaopetus (accessed 20 July 2015).

Sanders, K. and Canel, M. (Eds), (2013), Government Communication Cases and Challenges, 1st ed., Bloomsbury Academic, London.

Seeger, M. and Reynolds, B. (2009), "Crisis communication and public health. Integrated approaches and new imperatives", in Seeger, M., Sellnow, T.L. and Ulmer, R.R. (Eds), Crisis Communication and the Public Health, Hampton Press, New York, NY.

Seeger, M.W. (2006), "Best practices in crisis communication: an expert panel process", Journal of Applied Communication Research, Vol. 34 No. 3, pp. 232-244.

Sjöberg, L. (2001), "Limits of knowledge and the limited importance of trust", Risk Analysis, Vol. 21 No. 1, pp. 189-198.

Slovic, P. (1999), "Trust, emotion, sex, politics and science: surveying the risk-assessment battlefield”, Risk Analysis, Vol. 19 No. 4, pp. 689-701.

Streb, C. (2010), "Exploratory case study", in Mills, A., Durepos, G. and Wiebe, E. (Eds), Encyclopedia of Case Study Research, Sage Publications, Thousand Oaks, CA, pp. 372-374.

Downloaded by Tallinn University At 10:20 23 October 2016

STUK - Finnish Radiation and Nuclear Safety Authority (2015), “About us", available at: www. stuk.fi/web/en/about-us/organization (accessed 29 August 2015).

Sutton, J., Palen, L. and Shklovski, I. (2008), "Backchannels on the front lines: emergent uses of social media in the 2007 Southern California wildfires", in Fiedrich, F. and Van de Walle, B. (Eds), Proceedings of the 5th International ISCRAM Conference, The George Washington University, Washington DC, pp. 624-632.

Taylor, M., Wells, G., Howell, G. and Raphael, B. (2012), "The Role of social media as psychological first aid as a support to community resilience building", The Australian Journal of Emergency Management, Vol. 27 No. 1, pp. 22-26.

Theunissen, P. and Wan Noordin, W.N. (2012), "Revisiting the concept 'dialogue' in public relations", Public Relations Review, Vol. 38 No. 1, pp. 5-13.

Thijs, N. and Staes, P. (2008), "European primer on customer satisfaction management", 5th European Quality Conference, EUPAN, Paris, pp. 20-22.

Tirkkonen, P. and Luoma-aho, V. (2011), "Online authority communication during an epidemic: a Finnish example”, Public Relations Review, Vol. 37 No. 2, pp. 172-174. 
Tirkkonen, P. and Luoma-aho, V. (2014), "Authority crisis communication vs discussion forums: swine flu", in DiStaso, M.W. and Bortree, D.S. (Eds), Ethical Practice of Social Media in Public Relations, Routledge, New York, NY, pp. 279-298.

Tuomi, J. and Sarajärvi, A. (2002), Laadullinen tutkimus ja sisällönanalyysi, Gummerus Kirjapaino Oy, Jyväskylä.

Ulmer, R.R., Sellnow, T.L. and Seeger, M.W. (2011), Effective Crisis Communication: Moving From Crisis to Opportunity, 2nd ed., Sage Publications, Thousand Oaks, CA.

Veil, S.R., Buehner, T. and Palenchar, M.J. (2011), "A work-in-process literature review: incorporating social media in risk and crisis communication”, Journal of Contingencies and Crisis Management, Vol. 19 No. 2, pp. 110-122.

Veil, S.R., Sellnow, T.L. and Petrun, E.L. (2012), "Hoaxes and the paradoxical challenges of restoring legitimacy: Dominos' response to Its Youtube crisis", Management Communication Quarterly, Vol. 26 No. 2, pp. 322-345.

Wester Herber, M. (2004), "Talking to me? - risk communication to a diverse public", doctoral dissertation, Örebro University, Örebro.

\section{Further reading}

Castells, M. (2007), "Communication, power and counter-power in the network society", International Journal of Communication, Vol. 1 No. 1, pp. 238-266. 